\title{
Comparison Between Phylogenetic Relationships Based on $18 S$ rDNA Sequences and Growth by Salinity of Chlorella-like Species (Chlorophyta)
}

\author{
Hye Jung Lee and Sung Bum Hur* \\ Department of Marine Bio-materials and Aquaculture, Pukyong National University, Busan 608-737, Korea
}

\begin{abstract}
This study was carried out to understand the correlation between phylogenetic relationships based on 18S rDNA sequences and growth by salinity of Chlorella-like species. The 18S rDNA sequences of 71 Chlorella-like species which were mainly collected from Korean waters were analyzed. The $18 \mathrm{~S}$ rDNA sequences of Chlorella-like species were divided into three groups (group A, B and C) and group B was further divided into three subgroups (subgroup B-1, B-2 and B-3). Thirty-seven Chlorella-like species in group A grew well at high salinity (32 psu) but the other groups grew well in freshwater. The sequence identities of the species in group A and B were 97.2-99.5\%, but those of 6 species in group C ("Chlorella" saccharophila), which contained group I intron sequences region were $75.0-75.4 \%$. Two representative species of each group were cultured at different salinities $(0,16$ and 32 psu) to examine the correlation between the molecular phylogenetic groups and the phenotypic characteristics on cell growth and size by different salinities. The size of cell cultured at different salinities varied according to the species of each molecular phylogenetic group. The size of "Chlorella" saccharophila in group C was bigger and more obviously elliptical rather than that of the other Chlorella-like species. Considering the results on molecular and phenotypic characteristics, the group A and B belonged to Chlorellaceae, but group $\mathrm{C}$ was distinctly different from them.
\end{abstract}

Keywords: Chlorella, Growth, Salinity, Size, 18S rDNA

\section{Introduction}

The genus Chlorella is unicellular green algae with sphere or elliptical shape of very small size around 2-10 $\mu \mathrm{m}$. Since Chlorella vulgaris Beijerinck, which was a type species of the genus Chlorella was isolated (Beijerinck, 1890), a number of Chlorella were widely studied or utilized as industrial materials (Scragg et al., 2003; Yoshida et al., 2006; Rioboo et al., 2009). Most of the coccoid green algae that are very small in size and similar in shape, classification of Chlorella has been considered as one of the most difficult studies in phylogenetic classification (Krienitz et al., 2004).

Though more than 100 species of coccoid green algae were classified as members of the genus Chlorella, most of them were transferred to other genus such as Micractinium, Didymogenes and Actinastrum through taxonomic studies based on morphological characters (Fott and Nováková, 1969; Andreyeva, 1975). Because of the lack of distinct morphological characters for species for identification of Chlorella, the ultrastructure of cell walls or pyrenoids (Ikeda and Takeda, 1995; Nemcová and Kalina, 2000), comparative physiology and biochemistry (Kessler and Huss, 1992; Kadono et al., 2004), and nutrient requirements (Shihira and Krauss, 1965; Wang and Dei, 2001), were often adopted for their precise classification.

Since the first report of $18 \mathrm{~S}$ ribosomal RNA gene (rDNA) sequence of the type species, C. vulgaris (Huss and Sogin,
Open Access http://dx.doi.org/10.5657/FAS.2012.0125

This is an Open Access article distributed under the terms of the Creative Commons Attribution Non-Commercial License (http://creativecommons. org/licenses/by-nc/3.0/) which permits unrestricted non-commercial use, distribution, and reproduction in any medium, provided the original work is properly cited.
Received 12 March 2012; Revised 10 May 2012

Accepted 13 May 2012

*Corresponding Author

E-mail: hurs@pknu.ac.kr 
1989) the polyphyly of the genus Chlorella was proposed based on 18S rDNA sequences information (Huss and Sogin, 1990; Friedl, 1997; Huss et al., 1999). After that, through accumulated biochemical data and analysis of $18 \mathrm{~S}$ rDNA sequences, only four "true" Chlorella species (C. kessleri, C. lobophora, C. sorokiniana, and C. vulgaris) was proposed (Huss et al., 1999). Besides, on the basis of the phylogenetic analysis of $18 \mathrm{~S}$ rDNA sequences, Krienitz et al. (2004) had suggested that the family Chlorellaceae is composed of Chlorella and Parachlorella clades. More recently, Luo et al. (2010) revealed that five genera of green algae (Micractinium, Didymogenes, Actinastrum, Meyerella, and Hegewaldia) were phylogenetically closely affiliated to the genus Chlorella inferred from nucleotide sequences of $18 \mathrm{~S}$ rDNA and ITS regions.

Korea Marine Microalgae Culture Center (KMMCC) had collected 80 species of Chlorella-like species from coastal and inland regions in Korea or from foreign collection centers (Hur, 2008). Chlorella-like species were identified at level of genus by observation of light microscopy, but it was confusing to identify at species level because of their similar morphology. In particular, Chlorella-like species isolated from estuary water was obscure to identify its origin as marine or freshwater species. Therefore, in this study, 18S rDNA sequences of 71 Chlorella-like species collected mainly from Korean waters were examined. In addition, growth and size of representative Chlorella-like species from each identified group were also tested at different salinities of culture media. And the correlation between molecular phylogenetic relationships and phenotypic characteristics on growth and size of Chlorella-like species was analyzed.

\section{Materials and Methods}

\section{S rDNA gene amplification and sequence analysis}

Seventy-one Chlorella-like species used in this study were received from KMMCC in Pukyong National University. Among them, six species were obtained from abroad and the rest of the 65 species were isolated from coastal and inland regions in Korea (Table 1). Forty six species of green algae which were used in the phylogenetic tree which were obtained from GenBank.

Chlorella-like species were stationary cultured in $150 \mathrm{~mL}$

Table 1. Culture history of seventy-one Chlorella-like species for the study and their GenBank accession numbers for the 18S rDNA sequences

\begin{tabular}{|c|c|c|c|c|}
\hline $\begin{array}{c}\text { KMМCC } \\
\text { No. }\end{array}$ & Species & $\begin{array}{c}\text { Source and } \\
\text { sampling area }\end{array}$ & $\begin{array}{c}\text { Accession } \\
\text { number }\end{array}$ & $\begin{array}{c}\text { Length of } \\
\text { sequence (bp) }\end{array}$ \\
\hline 2 & "Chlorella" ellipsoidea & UTEX 20 & HQ702324 & 2075 \\
\hline 3 & "Chlorella" saccharophila var. saccharophila & UTEX 247 & HQ702323 & 2075 \\
\hline 6 & Chlorella vulgaris & UTEX259 & GQ122369 & 1672 \\
\hline 8 & Chlorella sp. & Japan (Institute) & HQ702302 & 1672 \\
\hline 9 & Chlorella vulgaris & UTEX26 & GQ122370 & 1673 \\
\hline 29 & Chlorella sp. & Nakdong River & HQ702280 & 1672 \\
\hline 65 & Chlorella vulgaris & Yocheon & GQ122334 & 1672 \\
\hline 86 & Chlorella sp. & Deukryang bay & GQ122336 & 1672 \\
\hline 87 & Chlorella sp. & Namhae & HQ702304 & 1672 \\
\hline 115 & Chlorella sp. & Hwajinpo & HQ702296 & 1673 \\
\hline 132 & Chlorella sp. & Jinhae Bay & HQ702297 & 1672 \\
\hline 137 & Chlorella sp. & Nakdong River & HQ702276 & 1672 \\
\hline 138 & Chlorella vulgaris & Hwajinpo & HQ702293 & 1673 \\
\hline 143 & Chlorella vulgaris & Myungsun Co. & HQ702286 & 1672 \\
\hline 144 & Chlorella vulgaris & Sunwo Fresh Co. & HQ702289 & 1672 \\
\hline 145 & Chlorella vulgaris & Samhae Inter. Co. & HQ702288 & 1672 \\
\hline 146 & "Chlorella" saccharophila & Hwajinpo & HQ702321 & 2075 \\
\hline 148 & Chlorella vulgaris & South Sea & GQ122345 & 1672 \\
\hline 149 & Chlorella vulgaris & South Sea & GQ122346 & 1672 \\
\hline 156 & Chlorella vulgaris & Taejongdae & GQ122343 & 1672 \\
\hline 163 & Chlorella sp. & Tailand (Institute) & GQ122340 & 1672 \\
\hline 164 & Chlorella vulgaris & Gyunggi Bay & GQ122338 & 1672 \\
\hline 173 & Chlorella vulgaris & Namhae & HQ702318 & 1672 \\
\hline 174 & Chlorella vulgaris & Jinhae Bay & HQ702287 & 1672 \\
\hline 175 & Chlorella vulgaris & Jinhae Bay & HQ702294 & 1673 \\
\hline 183 & "Chlorella" saccharophila var. saccharophila & South Sea & HQ702326 & 2075 \\
\hline 190 & Chlorella vulgaris & Daebyun & HQ702309 & 1672 \\
\hline 191 & Chlorella vulgaris & South Sea & HQ702308 & 1672 \\
\hline 193 & Chlorella sp. & Andongho & GQ122372 & 1672 \\
\hline 211 & Chlorella sp. & Yosu & GQ122349 & 1672 \\
\hline 212 & Chlorella sp. & Yosu & HQ702313 & 1672 \\
\hline 221 & Chlorella sp. & Haeundae & HQ702319 & 1672 \\
\hline 234 & Chlorella sp. & Jindong & HQ702316 & 1672 \\
\hline 240 & Chlorella sp. & Jindong & HQ702301 & 1672 \\
\hline
\end{tabular}

KMMCC : Korea Marine Microalgae Culture Center ; UTEX : University of Texas Culture Collection; PKNU: pond of Pukyong National University. 
media volume of $250 \mathrm{~mL}$ Erlenmeyer flask using a temperature of $25^{\circ} \mathrm{C}$ with continuous illumination of $100 \mu \mathrm{mol}$ photons $\mathrm{m}^{-2} \mathrm{~s}^{-1}$ for 2 weeks. F/2 medium (Guillard and Ryther, 1962) for marine Chlorella-like species and Jaworski medium (Thompson et al., 1988) for freshwater Chlorella-like species were used. Cultured microalgae were harvested and their genomic DNA was isolated using $\mathrm{LiCl}$ method (Hong et al., 1995) or Wizard $^{\circledR}$ Genomic DNA Purification System (Promega, Medison, WI, USA). Isolated genomic DNA was performed polymerase chain reactions (PCR) using P2F (GGC TCA TTA AAT CAG TTA TAG) / MF (ACC TGG TTG ATC CTG CCA $\mathrm{G})$ forward primers and P2R (CCT TGT TAC GA(C/T) TTC TCC TTC) / RF (GTG AAC CTG C(G/A)G AAG GAT CA) reverse primers (Huss et al., 1999; Lee and Hur, 2009) for 18S rDNA gene amplification. Sequences were obtained from cloning and the sequencing process (Lee and Hur, 2009). Sequences were subjected to homology analysis by using Blast $\mathrm{N}$ program and aligned by using ClustalW2 program (Thomp- son et al., 1994). For these species, $18 \mathrm{~S}$ rDNA sequences were acquired and their accession numbers were registered in GenBank of NCBI.

Genetic distance of sequences was calculated by Kimura 2-parameter model (Kimura, 1980) and sequence identity was carried out by Bioedit Sequence Alignment Editor version 7.0.5.3. (Hall, 1999). To analyze the phylogenetic relationships of sequences, maximum likelihood (ML), maximum parsimony (MP), and neighbor joining (NJ) analysis were conducted using MEGA v.5.0 (Tamura et al., 2011). The ML analysis was constructed based on the Kimura 2-parameter with proportion of invariable sites and gamma distribution split into five categories $(\mathrm{K} 2+I+G)$. This model was selected by test as best-fit substitution model of nucleotide sequence data. The MP analysis was obtained using the Close- Neighbor-Interchange algorithm (Nei and Kumar, 2000) with search level 3 in which the initial trees were obtained with the random addition of sequences (100 replicates). The NJ analysis

Table 1. continued

\begin{tabular}{|c|c|c|c|c|}
\hline $\begin{array}{l}\text { KMMCC } \\
\text { No. }\end{array}$ & Species & $\begin{array}{c}\text { Source and } \\
\text { sampling area }\end{array}$ & $\begin{array}{c}\text { Accession } \\
\text { number }\end{array}$ & $\begin{array}{c}\text { Length of } \\
\text { sequence (bp) }\end{array}$ \\
\hline 241 & Chlorella sp. & Jindong & HQ702300 & 1672 \\
\hline 250 & Chlorella sp. & PKNU & HQ702284 & 1672 \\
\hline 252 & Chlorella sp. & Hongdo & HQ702299 & 1672 \\
\hline 253 & Chlorella sp. & Buan & HQ702317 & 1673 \\
\hline 274 & "Chlorella" saccharophila & PKNU & HQ702325 & 2075 \\
\hline 322 & Chlorella sp. & Busan & HQ702281 & 1672 \\
\hline 323 & Chlorella vulgaris & Busan & HQ702292 & 1673 \\
\hline 335 & "Chlorella" saccharophila & PKNU & HQ702277 & 2075 \\
\hline 336 & Chlorella sp. & PKNU & GQ122373 & 1672 \\
\hline 337 & Chlorella sp. & PKNU & HQ702283 & 1672 \\
\hline 338 & Chlorella sp. & PKNU & HQ702279 & 1672 \\
\hline 339 & Chlorella vulgaris & PKNU & HQ702285 & 1672 \\
\hline 345 & Chlorella sp. & South Sea & GQ122352 & 1672 \\
\hline 346 & Chlorella sp. & Haeundae & HQ702315 & 1672 \\
\hline 351 & Chlorella sp. & Gampo & GQ122357 & 1672 \\
\hline 352 & Chlorella sp. & PKNU & GQ122374 & 1672 \\
\hline 353 & Chlorella sp. & Busan & HQ702278 & 1672 \\
\hline 354 & Chlorella vulgaris & East Sea & GQ122359 & 1672 \\
\hline 355 & Chlorella vulgaris & PKNU & HQ702295 & 1673 \\
\hline 392 & Chlorella sp. & Buan & GQ122354 & 1672 \\
\hline 393 & Chlorella sp. & Buan & HQ702311 & 1672 \\
\hline 394 & Chlorella sp. & Haeundae & HQ702312 & 1672 \\
\hline 404 & Chlorella sp. & Nakdong River & HQ702291 & 1672 \\
\hline 434 & Chlorella sp. & Donghae & HQ702306 & 1672 \\
\hline 449 & Chlorella sp. & Nakdong River & HQ702307 & 1672 \\
\hline 859 & Chlorella sp. & Buan & HQ702298 & 1672 \\
\hline 860 & Chlorella sp. & Buan & HQ702320 & 1672 \\
\hline 870 & Chlorella sp. & Geum River & HQ702310 & 1672 \\
\hline 882 & Chlorella sp. & Nakdong River & HQ702290 & 1672 \\
\hline 883 & Chlorella sp. & Namdaechoen & GQ122376 & 1672 \\
\hline 1006 & Chlorella sp. & Wando & GQ122360 & 1672 \\
\hline 1007 & Chlorella sp. & Asan Bay & HQ702303 & 1672 \\
\hline 1008 & Chlorella sp. & Wando & HQ702305 & 1672 \\
\hline 1009 & Chlorella sp. & Uljin & GQ122361 & 1672 \\
\hline 1058 & Chlorella sp. & Nakdong River & HQ702314 & 1672 \\
\hline 1205 & Chlorella sp. & Upo & GQ122378 & 1672 \\
\hline 1226 & Chlorella sp. & Nakdong River & HQ702282 & 1672 \\
\hline
\end{tabular}

KMMCC : Korea Marine Microalgae Culture Center ; UTEX : University of Texas Culture Collection; PKNU: pond of Pukyong National University. 
model was used for maximum composite likelihood and 2000 bootstrap replications were carried out to support the reliability of the tree and the species with similar sequences were grouped together.

\section{Growth and size of representative species from each group at different salinities}

Growth characteristics of the species from each group were examined and compared to each other. Two representative species showing the difference on the phylogenetic relationships of sequences from each group were selected and cultured at different salinities $(0,16$, and $32 \mathrm{psu})$. The specific growth rate (s.g.r./day=3.322 $\times \log \left(\mathrm{N}_{1} / \mathrm{N}_{0}\right) / \mathrm{t}_{1}-\mathrm{t}_{0}\left(\mathrm{~N}_{1}\right.$ and $\mathrm{N}_{0}$ : cell number at $t_{1}$ and $t_{0}$ day)) (Guillard, 1973) and size of the cell were examined. For this culture, f/2 medium (32 psu) was used for marine Chlorella-like species. For estuary and freshwater Chlorella-like species, nutrient concentrations of $\mathrm{f} / 2$ medium were also used and the salinity for estuary (16 psu) and freshwater (0 psu) Chlorella-like species was made with distilled water and sea water. Microalgae were cultured in $250 \mathrm{~mL}$ Erlenmeyer flask with $100 \mathrm{~mL}$ medium at $25^{\circ} \mathrm{C}$ with continuous light of $100 \mu \mathrm{mol}$ photons $\mathrm{m}^{-2} \mathrm{~s}^{-1}$ for 10 days. Culture experiments were replicated three times. The cell number of microalgae was counted daily using a hemacytometer. The size of 40 cells at the initial and final culture days was measured using MoticamPro 205A CCD scientific camera (Motic Instruments Inc., Richomond, BC, Canada).

\section{Statistical analysis}

Data were analyzed by one-way ANOVA test, and Duncan's multiple range test (Duncan, 1955) was applied for the significance level $(P<0.05)$. SPSS version 10.1 (SPSS Inc., Chicago, IL, USA) was used for all statistical analysis.

\section{Results and Discussion}

\section{Analysis of 18S rDNA sequences}

Molecular phylogenetic analysis of $18 \mathrm{~S}$ rDNA sequences from 71 Chlorella-like species showed three independent groups (group A, B and C) with 94-99\% bootstrap value. Group B was divided into three subgroups (subgroup B-1, B-2, and B-3) (Fig 1.). Maximum likelihood phylogenetic analysis by using 21 representative species of the acquired Chlorella-like species sequences and 46 species of green algae sequences referred from GenBank also confirmed three groups with $97-100 \%$ bootstrap value (Fig. 2). Sequence identity and genetic distance of 10 species (group A: KMMCC-234, 870; group B-1: KMMCC-9, 115; group B-2: KMMCC-132, 137; group B-3: KMMCC-6, 143; group C: KMMCC-3, 183) which were composed with two representative species from each of the five groups as well as six species obtained from GenBank were analyzed (Table 2). The sequence identity of KMMCC-234 and 870 from group A was $99.5 \%$. Sequence

Table 2. Percentage of sequence identity (top right triangle) and nucleotide pairwise distance calculation (bottom left triangle) of the $18 \mathrm{~S}$ rDNA sequences of ten representative Chlorella-like species and six species from Genbank

\begin{tabular}{|c|c|c|c|c|c|c|c|c|c|c|c|c|c|c|c|c|c|}
\hline No. & Species & 1 & 2 & 3 & 4 & 5 & 6 & 7 & 8 & 9 & 10 & 11 & 12 & 13 & 14 & 15 & 16 \\
\hline 1 & Chlorella sp. KMMCC-234 & - & 99.5 & 97.3 & 97.3 & 97.5 & 97.2 & 97.7 & 97.4 & 75.0 & 75.0 & 99.5 & 98.7 & 97.7 & 97.3 & 97.5 & 75.0 \\
\hline 2 & Chlorella sp. KMMCC-870 & 0.0031 & - & 97.6 & 97.5 & 97.9 & 97.6 & 97.9 & 97.6 & 75.1 & 75.1 & 100.0 & 98.9 & 98.0 & 97.5 & 97.9 & 75.1 \\
\hline 3 & Chlorella sp. KMMCC-9 & 0.0245 & 0.0213 & - & 98.5 & 98.9 & 99.4 & 98.9 & 98.7 & 75.2 & 75.2 & 97.6 & 97.3 & 99.1 & 99.0 & 99.7 & 75.2 \\
\hline 4 & Chlorella sp. KMMCC-132 & 0.0251 & 0.0232 & 0.0125 & - & 99.0 & 98.5 & 99.1 & 98.8 & 75.2 & 75.2 & 97.5 & 97.2 & 99.2 & 99.0 & 98.8 & 75.2 \\
\hline 5 & Chlorella sp. KMMCC-137 & 0.0226 & 0.0194 & 0.0087 & 0.0100 & - & 98.8 & 99.2 & 99.0 & 75.4 & 75.4 & 97.9 & 97.4 & 99.5 & 98.8 & 99.2 & 75.4 \\
\hline 6 & Chlorella sp. KMMCC-115 & 0.0245 & 0.0213 & 0.0050 & 0.0125 & 0.0087 & - & 98.8 & 98.6 & 75.2 & 75.2 & 97.6 & 97.3 & 99.0 & 99.0 & 99.6 & 75.2 \\
\hline 7 & Chlorella vulgaris KMMCC-6 & 0.0213 & 0.0194 & 0.0087 & 0.0075 & 0.0062 & 0.0087 & - & 99.3 & 75.4 & 75.4 & 97.9 & 97.7 & 99.6 & 99.1 & 99.2 & 75.4 \\
\hline 8 & Chlorella vulgaris KMMCC-143 & 0.0245 & 0.0226 & 0.0118 & 0.0106 & 0.0093 & 0.0118 & 0.0056 & - & 75.2 & 75.2 & 97.6 & 97.4 & 99.4 & 98.8 & 98.9 & 75.2 \\
\hline 9 & $\begin{array}{l}\text { "Chlorella" saccharophila var. saccharophila } \\
\text { KMMCC-3 }\end{array}$ & 0.0620 & 0.0613 & 0.0595 & 0.0587 & 0.0567 & 0.0595 & 0.0560 & 0.0594 & - & 100.0 & 75.1 & 75.1 & 75.5 & 75.4 & 75.4 & 100.0 \\
\hline 10 & $\begin{array}{l}\text { "Chlorella" saccharophila var. saccharophila } \\
\text { KMMCC-183 }\end{array}$ & 0.0620 & 0.0613 & 0.0595 & 0.0587 & 0.0567 & 0.0595 & 0.0560 & 0.0594 & 0.0000 & - & 75.1 & 75.1 & 75.5 & 75.4 & 75.4 & 100.0 \\
\hline 11 & Chlorella sp. KAS 012 & 0.0031 & 0.0000 & 0.0213 & 0.0232 & 0.0194 & 0.0213 & 0.0194 & 0.0226 & 0.0613 & 0.0613 & - & 98.9 & 98.0 & 97.5 & 97.9 & 75.1 \\
\hline 12 & Parachlorella kessleri SAG 211-11g & 0.0093 & 0.0087 & 0.0238 & 0.0245 & 0.0219 & 0.0239 & 0.0194 & 0.0226 & 0.0600 & 0.0600 & 0.0087 & - & 97.7 & 97.2 & 97.5 & 75.1 \\
\hline 13 & Chlorella sorokiniana SAG 211-8k & 0.0207 & 0.0175 & 0.0068 & 0.0068 & 0.0043 & 0.0068 & 0.0019 & 0.0050 & 0.0554 & 0.0554 & 0.0175 & 0.0187 & - & 99.2 & 99.3 & 75.5 \\
\hline 14 & Chlorella lobophora Andreyeva 748-I & 0.0251 & 0.0232 & 0.0074 & 0.0087 & 0.0100 & 0.0075 & 0.0075 & 0.0106 & 0.0567 & 0.0567 & 0.0232 & 0.0245 & 0.0068 & - & 99.3 & 75.4 \\
\hline 15 & Chlorella vulgaris SAG 211-11 b & 0.0219 & 0.0188 & 0.0025 & 0.0100 & 0.0062 & 0.0025 & 0.062 & 0.0093 & 0.0567 & 0.0567 & 0.0188 & 0.0213 & 0.0043 & 0.0050 & - & 75.4 \\
\hline 16 & "Chlorella" saccharophila SAG 211-1 d & 0.0620 & 0.0613 & 0.0595 & 0.0587 & 0.0567 & 0.0595 & 0.0560 & 0.0594 & 0.0000 & 0.0000 & 0.0613 & 0.0600 & 0.0554 & 0.0567 & 0.0567 & - \\
\hline
\end{tabular}

KAS: Korean Algae from Seawater; KMMCC: Korea Marine Microalgae Culture Center; SAG: Sammlung von Algenkulturen der Universität Göttingen. 


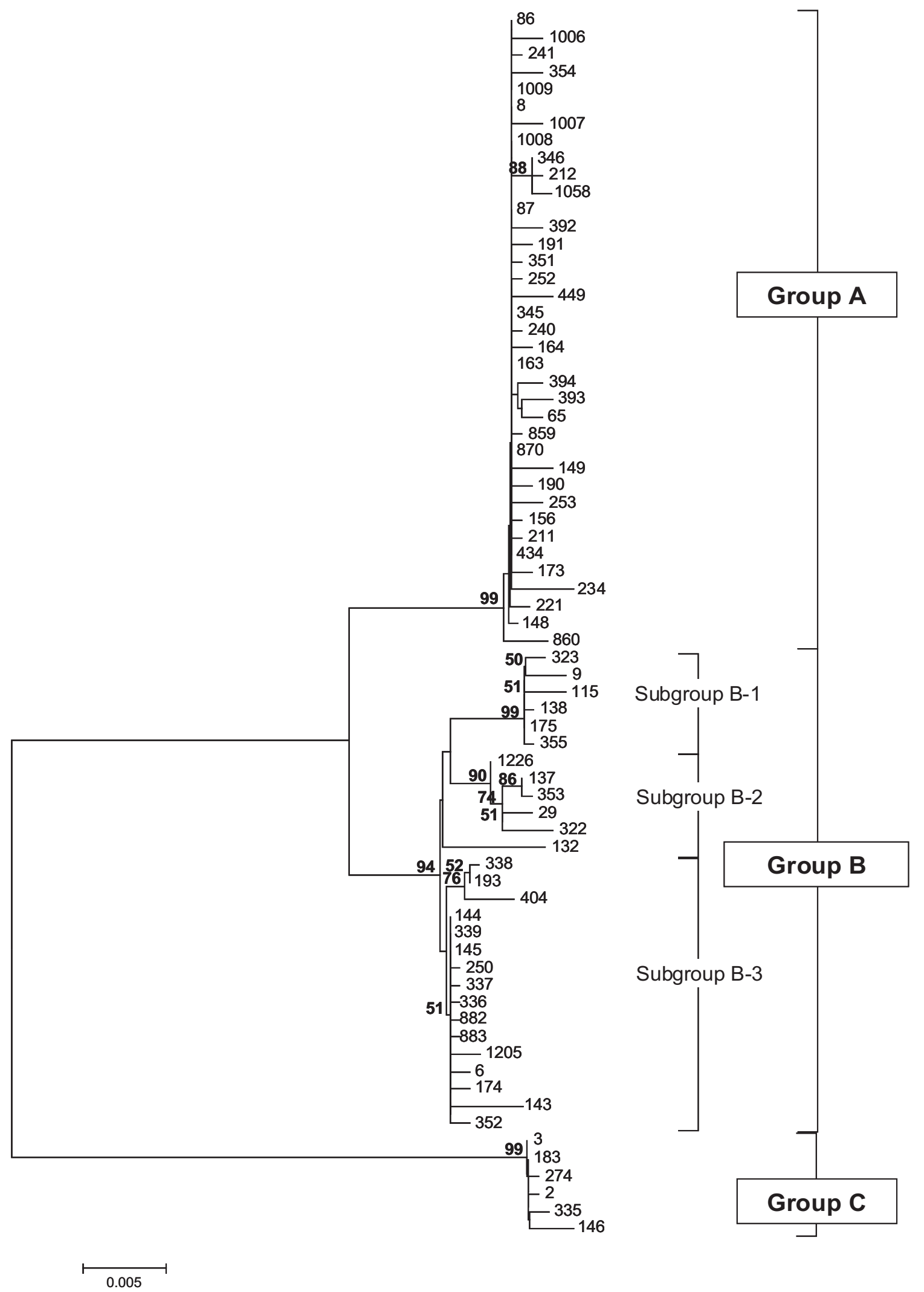

Fig. 1. Molecular phylogenetic tree using the Neighbor-joining method inferred from $18 \mathrm{~S}$ ribosomal DNA sequences of 71 Chlorella-like species. Tree reliability is tested by 2000 bootstraps, which indicates numbers (bold letters) at the nodes. Only values above $50 \%$ are shown. 


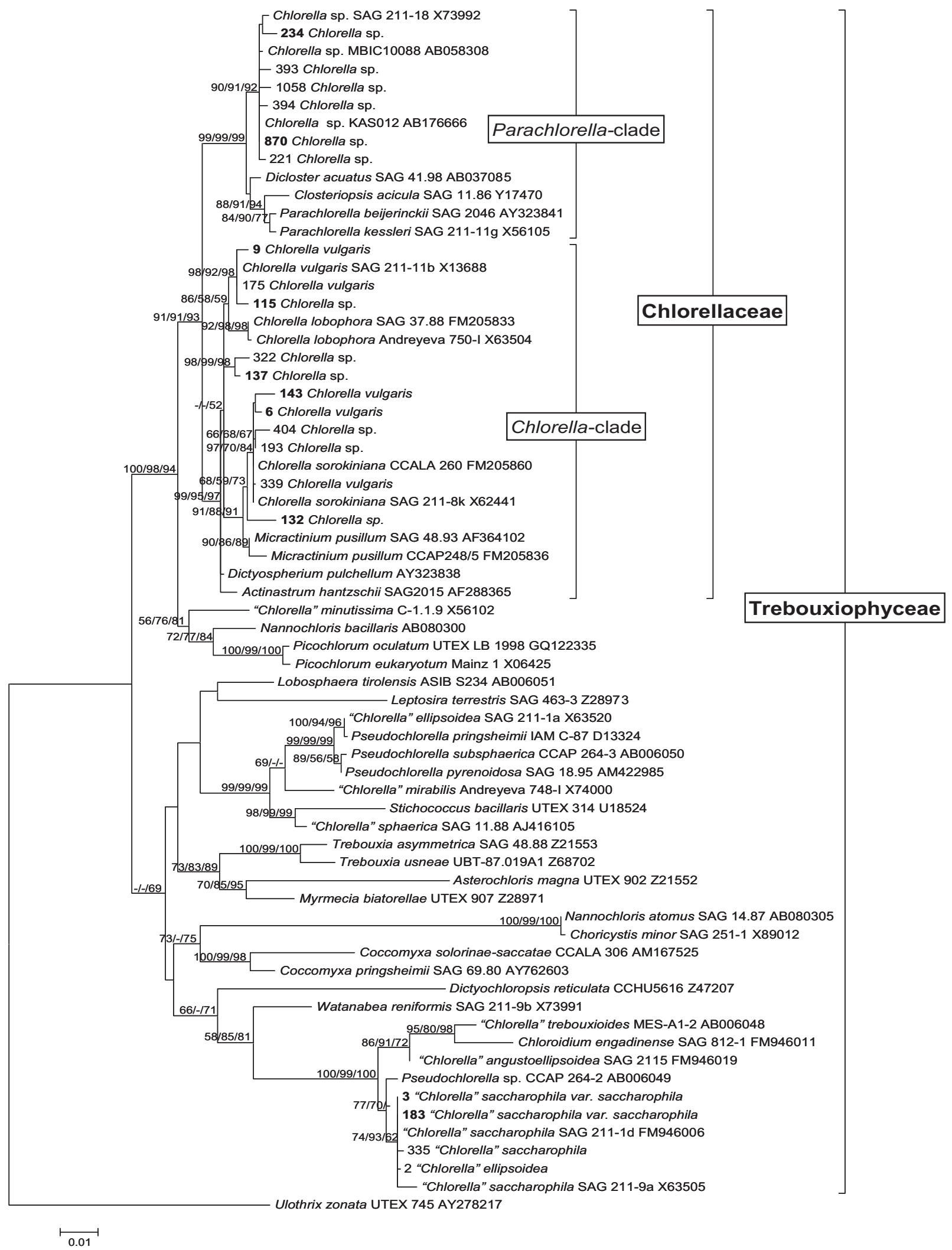

Fig. 2. Maximum-likelihood tree of $18 \mathrm{~S}$ rDNA sequences from members of the Trebouxiophyceae. Numbers above the nodes indicate support bootstrap values of maximum-likelihood (right), maximum-parsimony (middle) and neighbor-joning (left) analysis. Only values above $50 \%$ are shown. Ten representative species from each group are indicated as bold letters. Ulothrix zonata is indicated for one group. 
identity compared with group A and group B showed 97.2$97.9 \%$, and that between KMMCC-3 and 183 from group $\mathrm{C}$ turned out to be same. However, group $\mathrm{C}$ showed low sequence identity of $75.0-75.4 \%$ with group A and B.

Group A was diverged monophyletic with bootstrap value of $99 \%$ in Fig. 2. Thirty-seven species which corresponded to $52.1 \%$ of total were included in this group. Most of the species collected from Korean coastal waters belonged to this group. The length of $18 \mathrm{~S}$ rDNA sequences of the species in group A was same with 1672 bp. Nine species (KMMCC-8, 86, 87, $163,345,434,870,1008$, and 1009) which composed $24.3 \%$ of group A were identical in sequence and other 28 species showed sequence differences of 1-7 bp. The representative species (KMMCC-234 and 870) of group A were located in same clade with Parachlorella beijerinckii and P. kessleri and sequence identity between genus Parachlorella and species of group A was 98.7-98.9\% with sequence differences of 15-21 bp. However, genus Parachlorella was closer to Closteriopsis acicula and Dicloster acuatus than group A and formed different cluster from group A. Moreover, Parachlorella was freshwater species, but most of species of group A were marine.

Chlorella sp. KAS 012 isolated from Korean sea water showed high sequence similarity over $99.5 \%$ with group A. This species exhibited very small and simple spherical morphology that was similar with the strains of Parachlorella (Aslam et al., 2007) although several egg-shaped cells of Parachlorella were observed (Krienitz et al., 2004). And Chlorella sp. KAS 012 possessed halotolerant and thermotolerant features. Aslam et al. (2007) proposed Chlorella sp. KAS 012 to genus Marinichlorella on the basis of the phenotypic and phylogenetic data. Therefore, it was judged that marine habitat species existed in Parachlorella clade. Chlorella sp. KMMCC-870 which was isolated from estuary of Geumriver was considered as a freshwater species on account of low salinity of sampling area. But this species was revised as a marine species. This misunderstanding was due to tidal currents in the estuary area.

Group B was diverged with $94-99 \%$ bootstrap value and 28 species which composed of $39.4 \%$ of total species were included in this group. Two species from UTEX (KMMCC-6 and 9) and 26 species collected from the inland area were included in this group and their sequence length was 16721673 bp. Group B was divided into three subgroups. Chlorella vulgaris Beijerinck SAG 211-11b belonged to subgroup B-1. Sequence length of six species in subgroup B-1 showed same length with 1673 bp and over 99.4\% identity with only 1-4 bp sequence differences (Fig. 2). Five among six species in subgroup B-2 were collected from Nakdong-river and Namcheon-cheon. The sequence length of the five species was the same with 1672 bp and sequence identity was $99.5-99.9 \%$ with only 1-5 bp sequence differences. However, in case of Chlorella sp. KMMCC-132 collected from Jinhae Bay, sequence difference was $13 \mathrm{bp}$ which had large difference. And sequence identity was also slightly low (98.8-99.2\%). In com- parison with subgroup B-1, it showed similar tendency with 98.5-98.9\% of sequence similarity and 18 bp of sequence differences. Therefore, the position of KMMCC-132 in group B was not clear. The sequence length of 16 species in subgroup B-3 which were collected from freshwater was $1672 \mathrm{bp}$. The sequence identity was over $99.1 \%$ and sequence difference was $1-7$ bp in subgroup B-3. In the molecular phylogentic tree with 71 Chlorella-like species (Fig. 1), subgroup B-1 and B-2 were closely located, but B-3 was distantly diverged. It indicated that subgroup B-1 and B-2 were closer to each other. However, in Fig. 2, subgroup B-1, B-2, and B-3 were located next to each other, together with Actinastrum hantzschii and Dictyospherium pulchellum.

Group C was branched with 99-100\% bootstrap value and six species of "Chlorella" saccharophila were included in group C. The sequence length of them was 2075 bp and sequence identity was $99.6-100 \%$ with $1-5$ bp of sequence differences. Group C included group I intron of $400 \mathrm{bp}$ sequences and neighbored with Watanabea reniformis (Hanagata et al., 1998) forming a monophyletic lineage within Trebouxiophyceae. Group C was also considerably apart from group A and B in the tree. Friedl (1995) established new class Trebouxiophyceae by analysis of the ribosomal RNA sequences from coccoid green algae, which was the sister group of Chlorophyceae. Huss et al. (1999) reported four species of 'true' Chlorella belong to familiy Chlorellaceae in class Trebouxiophyceae. "Chlorella" saccharophila did not belong to the true Chlorella group (Huss et al., 2002).

In this study, group A and B belonged to Chlorellaceae which were diverged with $91-93 \%$ high bootstrap value in the phylogenetic tree (Fig. 2), but the another group of Trebouxiophyceae was diverged with $49-69 \%$ low bootstrap value. This finding was similar to the result (45-59\%) of Huss et al. (1999). This study also supported that "Chlorella" saccharophila of group $\mathrm{C}$ was not in 'true' Chlorella group. And taxonomic status of the group $\mathrm{C}$ species was unclear.

\section{Specific growth rate and size of cell by salinity}

The specific growth rate by salinity of two representative Chlorella-like species from each group was shown in Fig. 3. Group A showed the highest growth rate, whereas group $\mathrm{C}$ showed the lowest growth rate $(P<0.05)$. Group B showed intermediate tendency in growth rate. The specific growth rate of Chlorella sp. KMMCC-870 and 234 in group A was 0.75 and 0.55 , respectively at $32 \mathrm{psu}$, which were significantly higher than that at 16 and 0 psu. The growth rate of both species at 0 psu was lowest with $0.46(P<0.05)$. Six species in group B showed the fastest growth rate at 0 psu with $0.24-$ 0.45 compared with $0.01-0.29$ at 32 psu. In particular, subgroup B-3 showed the lowest growth rate with 0.01 at $32 \mathrm{psu}$ as compared with that of B-1 and B-2. KMMCC-3 and 183 in group $\mathrm{C}$ showed growth rate of $0.13-0.18$ at 0 and $16 \mathrm{psu}$, which were the lowest among the ten species. These species 


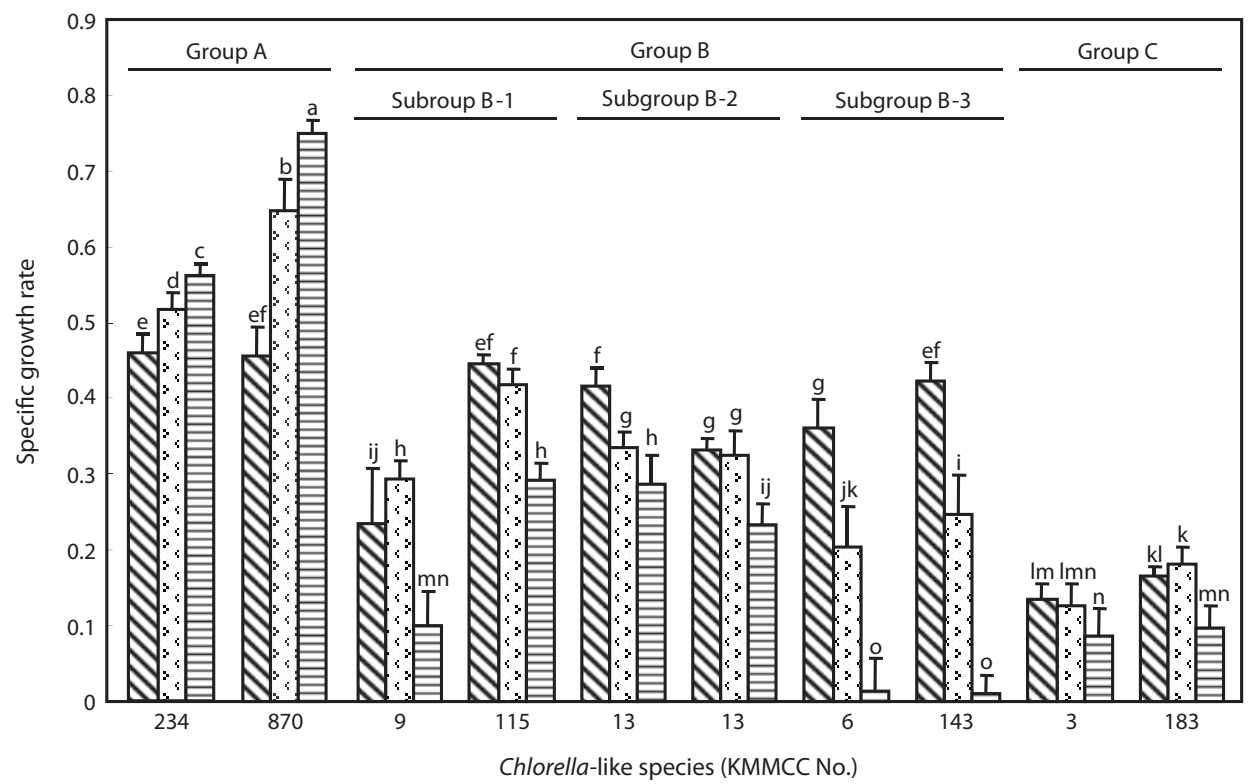

Fig. 3. Specific growth rate of ten representative Chlorella-like species cultured at different salinities $(\varangle: 0 \mathrm{psu} ;:: 16 \mathrm{psu} ; \boxminus: 32 \mathrm{psu})$. The different letters on the bar mean a significant difference $(P<0.05)$. KMMCC: Korea Marine Microalgae Culture Center.

showed significant high growth rate at 0,16 psu rather than 32 psu $(P<0.05)$.

With regards to cell size after 10 days of culture at different salinities (Fig. 4), the size of KMMCC-234 and 870 in group A were $3.12 \mu \mathrm{m}$ and $3.60 \mu \mathrm{m}$, respectively at $32 \mathrm{psu}$. However, the cell sizes of two species at 16 psu were 3.63 $\mu \mathrm{m}$ and $3.94 \mu \mathrm{m}$, and those were $3.94 \mu \mathrm{m}$ and $4.36 \mu \mathrm{m}$ at 0 psu, respectively. The cell size of KMMCC-234 and 870 was significantly larger in lower salinity $(P<0.05)$. The size at the final day showed a decreased tendency compared to that at inoculation day at $32 \mathrm{psu}$. In the case of KMMCC-870 which was collected at the Geum-river, the cell size was larger as with its lower salinity. This result was also in conformity with molecular phylogenetic analysis and cell growth rate as salinity, suggesting that it was originally a marine species.

The cell size of six species (KMMCC-6, 9, 115, 132, 137, and 143) in group B varied from $3.49 \mu \mathrm{m}$ to $4.93 \mu \mathrm{m}$ at $0 \mathrm{psu}$ after 10 days of culture. The cell size was $3.91-5.43 \mu \mathrm{m}$ at 16 psu and 4.59-7.70 $\mu \mathrm{m}$ at $32 \mathrm{psu}$. Especially the cell size of $C$. vulgaris KMMCC-6 and 143 in subgroup B-3 was $3.77 \mu \mathrm{m}$ and $3.49 \mu \mathrm{m}$, respectively at $0 \mathrm{psu}$. The final size of the species was not significantly different compared with initial size. But the cell sizes of them were $4.96 \mu \mathrm{m}$ and $5.18 \mu \mathrm{m}$, respectively at $16 \mathrm{psu}$, and $5.85 \mu \mathrm{m}$ and $7.25 \mu \mathrm{m}$, respectively at $32 \mathrm{psu}$. The cell sizes were larger at higher salinity $(P<0.05)$. Among these, the difference in cell size of KMMCC-143 between 0 psu and 32 psu was more than two times. The cell size of the species in group A and B showed significantly larger as the conditions of salinity when compared to the optimum salinity for growth rate.

Group C showed no significant difference in cell size by sa- linity, which was contrary to that of both group A and B. This feature also corresponded with molecular phylogenetic analysis. The cell size of microalgae increased under unsuitable salinity conditions due to effect of proline (Szekely, 2004). Proline increased the size of the cytoplasm and free water contents along with glycine betain (Record et al., 1998) and engaged in increased salt resistance of microalgae (Hiremath and Matad, 2010).

Elliptical "Chlorella" saccharophila were characterized by unequal size of autospores during sporogenesis (Fott and Nováková, 1969). This feature has the advantage of survival under unsuitable environments (Darienko et al., 2010). Bigger autospores increased proliferation rate than smaller ones, while smaller ones were widely spread by the wind. So, "Chlorella" saccharophila were found in a wide range of extreme environmental conditions such as exposure to trees, rocks, and acidic soil or high temperature soil (Kessler, 1965; Huss et al., 2002; Mikhailyuk et al., 2003; Gray et al., 2007). Because of the morphological and taxonomical differentiation from 'true' Chlorella, Darienko et al. (2010) proposed that "Chlorella" saccharophila be transferred to the Chloroidium saccharophilum.

In conclusion, the three groups of Chlorella-like species based on the sequence analysis of $18 \mathrm{~S}$ rDNA showed corresponding tendency with growth and size variation of the cell cultured at different salinities. Thus, the comparison between phylogenetic relationships based on $18 \mathrm{~S}$ rDNA sequences and phenotypic growth characteristics on salinity in the culture experiment can be considered as an useful method for systematic classification of Chlorella-like species which are difficult to identify. 

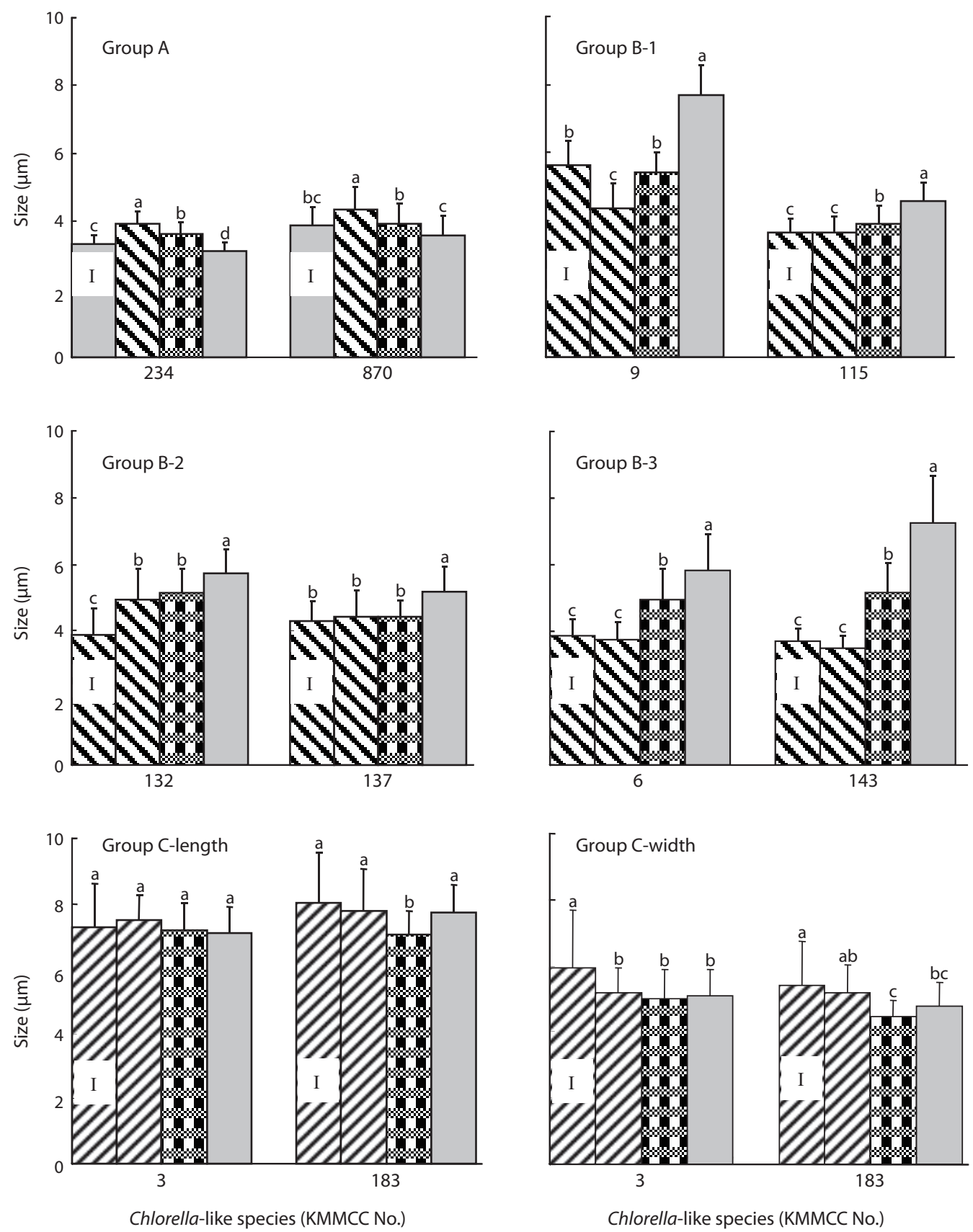

Fig. 4. Size variations of Chlorella-like species cultured at different salinities during ten days ( I : size at the inoculation day; 四:0 psu; 嘈 : 16 psu; $\square: 32$ psu). The different letters on the bar mean a significant difference $(P<0.05)$. KMMCC: Korea Marine Microalgae Culture Center.

\section{Acknowledgments}

This work was supported by the National Research Foundation of Korea (NRF) grant funded by the Korean government (MEST) (No. 2011-0027480) and the Marine Biomaterials Research Center grant from Marine Biotechnology Program funded by the Ministry of Land, Transport and Maritime Affairs, Korea.

\section{References}

Andreyeva VM. 1975. Rod Chlorella: morfologya, sistematika, printsipy klassifikatsii. Nauka, Leningrad, 88 pp.

Aslam Z, Shin W, Kim MK, Im WT and Lee ST. 2007. Marinichlorella

kaistiae gen. et sp. nov. (Trebouxiophyceae, Chlorophyta) based on polyphasic taxonomy. J Phycol 43, 576-584.

Beijerinck MW. 1890. Culturversuche mit zoochlorellen, lichenengo- 
niden und anderen niederen algen I-III. Botanische Zeitung 48, 726-740.

Darienko T, Gustavs L, Mudimu O, Menendez CR, Schumann R, Karsten U, Friedl T and Pröschold T. 2010. Chloroidium, a common terrestrial coccoid green alga previously assigned to Chlorella (Trebouxiophyceae, Chlorophyta). Eur J Phycol 45, 79-95.

Duncan DB. 1955. Multiple range and multiple $F$ tests. Biometrics 11, $1-42$.

Fott B and Nováková M. 1969. A monograph of the genus Chlorella. The fresh water species. In: Studies in phycology. Fott B, ed. Academia, Prague, 10-74.

Friedl T. 1995. Inferring taxonomic positions and testing genus level assignments in coccoid green algae: a phylogenetic analysis of $18 \mathrm{~S}$ ribosomal RNA sequences from Dictyochloropsis reticulata and from members of the genus Myrmecia (Chlorophyta, Trebouxiophyceae cl. nov.). J phycol 31, 632-639.

Friedl T. 1997. The evolution of the green algae. Plant Syst Evol Suppl 11, 87-101.

Gray DW, Lewis LA and Cardon ZG. 2007. Photosynthetic recovery following desiccation of desert green algae (Chlorophyta) and their aquatic relatives. Plant Cell Environ 30, 1240-1255.

Guillard RRL. 1973. Division rates. In: Handbook of Phycological Methods: Culture Methods and Growth Measurements. Stein JR ed. Cambridge University Press, London, U.K., 289-311.

Guillard RRL and Ryther JH. 1962. Studies on marine planktonic diatoms. Cyclotella nana Hustedt and Detonula confervacea (Clece) Gran. Can J Microbiol 3, 229-239.

Hanagata N, Karube I, Chihara M and Silva PC. 1998. Reconsideration of the taxonomy of ellipsoidal species of Chlorella (Trebouxiophyceae, Chlorophyta), with establishment of Watanabea gen. nov. Phycol Res 46, 221-229.

Hall TA. 1999. Bioedit: a user-friendly biological sequence alignment editor and analysis program for Windows 95/98/NT. Nucl Acids Symp Ser 41, 95-98.

Hiremath S and Mathad P. 2010. Impact of salinity on the physiological and biochemical traits of Chlorella vulgaris Beijerinck. J Algal Biomass Utln 1, 51-59.

Hong YK, Kim SD, Polne-Fuller M and Gibor A. 1995. DNA extraction conditions from Porphyra perforata using LiCl. J Appl Phycol 7, 101-107.

Hur SB. 2008. Korea Marine Microalgae Culture Center-List of strains. Algae 23, 1-68.

Huss VAR, Ciniglia C, Cennamo P, Cozzolino S, Pinto G and Pollio A. 2002. Phylogenetic relationships and taxonomic position of Chlorella-like isolates from low $\mathrm{pH}$ environments $(\mathrm{pH}<3.0)$. BMC Evol Biol 26, 2-13.

Huss VAR, Frank C, Hartmann EC, Hirmer M, Kloboucek A, Seidel BM, Wenzeler P and Kessler E. 1999. Biochemical taxonomy and molecular phylogeny of the genus Chlorella sensu lato (Chlorophyta). J Phycol 35, 587-598.

Huss VAR. and Sogin ML. 1989. Primary structure of the Chlorella vulgaris small subunit ribosomal RNA coding region. Nucl Acids Res 17, 1255.

Huss VAR and Sogin ML. 1990. Phylogenetical position of some
Chlorella species within the Chlorococcales based upon complete small-subunit ribosomal RNA sequences. J Mol Evol 31, 431-442.

Ikeda T and Takeda H. 1995. Species-specific differences of pyrenoids in Chlorella (Chlorophyta). J Phycol 35, 587-598.

Kadono T, Kawano T, Hosoya H and Kosaka T. 2004. Flow cytometric studies of the host-regulated cell cycle in algae symbiotic with green paramecium. Protoplasma 223, 133-141.

Kessler E. 1965. Physiologische und biochemische beiträge zur taxonomie der gattung Chlorella. I. Säureresistenz als taxonomisches merkmal. Arch Mikrobiol 52, 291-296.

Kessler E and Huss VAR. 1992. Comparative physiology and biochemistry and taxonomic assignment of the Chlorella (Chlorophyceae) strains of the culture collection of the university of Texas at Austin. J Phycol 28, 550-553.

Kimura M. 1980. A simple method for estimating evolutionary rates of base substitutions through comparative studies of nucleotide sequences. J Mol Evol 16, 111-120.

Krienitz L, Hegewald EH, Hepperle D, Huss VAR, Rohr T and Wolf M. 2004. Phylogenetic relationship of Chlorella and Parachlorella gen. nov. (Chlorophyta, Trebouxiophyceae). Phycologia 43, 529542.

Lee HJ and Hur SB. 2009. Genetic relationships among multiple strains of the genus Tetraselmis based on partial 18S rDNA sequences. Algae 24, 205-212.

Luo W, Pröschold T, Bock C and Krienitz L. 2010. Generic concept in Chlorella-related coccoid green algae (Chlorophyta, Trebouxiophyceae). Plant Biol 12, 545-223.

Mikhailyuk TI, Demchenko EM and Kondratyk SY. 2003. Algae of granite outcrops from the left bank of Pivdennyi bug river (Ukraine). Biologia 58, 589-601.

Nei M and Kumar S. 2000. Molecular Evolution and Phylogenetics. Oxford University Press, New York, 115-140.

Nemcová Y and Kalina T. 2000. Cell wall development, microfibril and pyrenoid structure in type strains of Chlorella vulgaris, C. kessleri, C. sorokiniana compared with C. luteoviridis (Trebouxiophyceae, Chlorophyta). Algological Studies 100, 95-105.

Record MT Jr, Couternay ES, Cayley S and Guttman JH. 1998. Biophysical compensation mechanism buffering E. coli proteins, nucleic acid interactions against changing environment. Trend Biochem Sci 23, 190-194.

Rioboo C, O'Connor JE, Prado R, Herrero C and Cid A. 2009. Cell proliferation alterations in Chlorella cells under stress conditions. Aquatic Toxicol 94, 229-237.

Scragg AH, Morrison J and Shales SW. 2003. The use of a fuel containing Chlorella vulgaris in a diesel engine. Enzyme Microb Technol 33, 884-889.

Shihira J and Krauss RW. 1965. Chlorella. Physiology and taxonomy of forty-one isolates. MD. Thesis, University of Maryland, Maryland , USA.

Szekely G. 2004. The role of proline in Arabidopsis thaliana osmotic stress response. Acta Biol Szeged 48, 81.

Tamura K, Peterson D, Peterson N, Stecher G, Nei M and Kumar S. 2011. MEGA5: Molecular evolutionary genetics analysis using maximum likelihood, evolutionary distance, and maximum parsi- 
mony methods. Mol Biol Evol 28, 2731-2739.

Thompson A, Rhodes J and Pettman I. 1988. Culture collection of algae and protozoa catalogue of strains. Natural Environment Research Council, Swindon. 164 pp.

Thompson JD, Higgins DG and Gibson TJ. 1994. Clustal W: Improving the sensitivity of progressive multiple sequence alignment through sequence weighting, position-specific gap penalties and weight matrix choice. Nucleic Acids Res 22, 4673-4680.

Wang WX and Dei RC. 2001. Effects of major nutrient additions on metal uptake in phytoplankton. Environ Pollut 111, 233-240.

Yosida N, Ikeda R and Okuno, T. 2006. Identification and characterization of heavy metal-resistant unicellular alga isolated from soil and its potential for phytoremediation. Bioresour Technol 97, 18431849. 